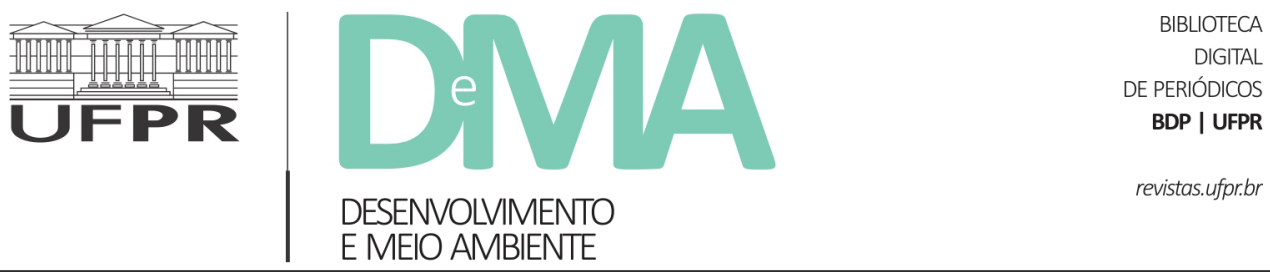

\title{
A review of ecosystems services trade-offs, synergies and scenarios modelling for policy development support
}

\section{Uma revisão sobre serviços ecossistêmicos, trade-offs, sinergias e modelagem de cenários para apoio ao desenvolvimento de políticas}

\author{
Priscila IKEMATSU ${ }^{1,2^{*}}$, José Alberto QUINTANILHA ${ }^{1}$ \\ ${ }^{1}$ Universidade de São Paulo (USP), São Paulo, SP, Brasil. \\ ${ }^{2}$ Instituto de Pesquisas Tecnológicas do Estado de São Paulo (IPT), São Paulo, SP, Brasil \\ *E-mail of contact: priscilai@ipt.br
}

Article received on April 14, 2020, final version accepted on September 10, 2020, published on December 22, 2020.

ABSTRACT: Information about the effect of land management on ecosystem services is essential to make balanced decisions, develop sustainable political strategies, and determine future scenarios. Previous methods and tools have been developed to analyze the effects of land use/land cover on ecosystem services. Nevertheless, being able to model the uncertainties, complexities, interconnections, and different interactions between multiple drivers of change in future scenario analysis are still a challenge in ecosystem service research. Modelling ecosystem service trade-offs and synergies and evaluating their use in scenario analysis are important issues that require more understanding. Therefore, this study explores the link and relationships among scenarios, models, and ecosystem services that support the decision-making processes. Based on electronic database publications, a conceptual framework illustrating the key components of this approach is presented. Further implications in terms of innovative tools that aim to identify pathways towards sustainable and balanced land use are also presented. It was concluded that spatial modelling of ecosystem services relationships associated with scenario building allows decision makers to better understand the complex interactions that occur in social-ecological systems. This approach brings important elements to set decisions, strategies, regulations, and policies for holistic land-use planning and management at different scales, notably in Brazil, a large and environmentally diversified country.

Keywords: ecosystem services modeling; land use management; future scenarios; decision making; environmental policy.

RESUMO: Informações sobre o efeito do manejo do uso da terra nos serviços ecossistêmicos são essenciais para tomar decisões equilibradas, desenvolver estratégias políticas sustentáveis e construir cenários futuros. Diversos 
métodos e ferramentas foram desenvolvidos para analisar os efeitos do uso/cobertura da terra nos serviços ecossistêmicos. No entanto, ser capaz de modelar incertezas, complexidades, interconexões e diferentes interações entre os vários vetores de mudança em análises de cenários futuros ainda é um desafio na pesquisa em serviços ecossistêmicos. Modelar trade-offs e sinergias entre esses serviços e avaliar o seu uso na análise de cenários são questões importantes que requerem mais entendimento. Portanto, este estudo explora o vínculo e as relações entre cenários, modelos e serviços ecossistêmicos como subsídio aos processos de tomada de decisão. Com base em publicações de bancos de dados eletrônicos, é apresentada uma estrutura conceitual que ilustra os principais componentes dessa abordagem. Outras implicações em termos de ferramentas inovadoras que visam identificar caminhos para um uso sustentável e equilibrado do solo também são apresentadas. Conclui-se que a modelagem espacial das relações de serviços ecossistêmicos associada à construção de cenários permite aos tomadores de decisão compreender melhor as complexas interações que ocorrem em sistemas socioecológicos. Esta abordagem traz elementos importantes para definir decisões, estratégias, regulamentos e políticas para o planejamento e gestão holística do uso da terra em diferentes escalas, notadamente no Brasil, um país grande e ambientalmente diversificado.

Palavras-chave: modelagem de serviços ecossistêmicos; gestão do uso da terra; cenários futuros; tomada de decisão; política ambiental.

\section{Introduction}

Ecosystem services (ES) are the goods/benefits that ecosystems provide to people (MEA, 2005) as well as their direct and indirect contributions to human well-being (Kosmus et al., 2012). Human pressures on natural resources have resulted in many ES changes, affecting biodiversity, natural habitats, food production, quality and quantity of fresh water, distribution of species, air quality, and pollution levels thereby affecting human well-being (Carpenter et al., 2005; MEA, 2005; Hernandez et al., 2010; Grizzetti et al., 2016).

After the Millennium Ecosystem Assessment (MEA, 2005), the importance of ES for human well-being was well established, which was reflected on the increasing number of scientific papers focusing on interrelations between nature and society through ES approaches (Barral \& Oscar, 2012). Numerous possible applications exist including sustainable management of natural resources, land use optimization, environmental protection, nature conservation and restoration, landscape planning, nature-based solutions, climate protection, disaster risk reduction, and environmental education and research (Burkhard \& Maes, 2017).

Assessing the mechanisms behind relationships between services (Bennett et al., 2009), such as trade-offs and synergies, is a key challenge for decision makers (Lee \& Lautenbach, 2016) because it provides information to identify pathways that minimize negative interactions and enhance positive ones.

Consequently, ES relationship analysis has become an important topic in ES research because they allow decision makers to predict ecosystem changes based on possible future land use scenarios and create a better understanding of the corresponding effects of different land management choices (Deng et al., 2016).

Many studies have explored trade-offs and synergies among the four categories of ES (provisio- 
ning, regulating, cultural, and supporting services) recognized by MEA (MEA, 2005). Furthermore, various fields have been analyzed using the ES approach, such as agriculture, tourism, energy, and ecological restoration. These fields encompassed different geographical features worldwide, including urban context (Haase et al., 2012; Lauf et al., 2014), urban-rural complexes (Yang et al., 2015; Moein et al., 2018), watersheds (Tian et al., 2016; Li \& Wang, 2018; Li et al., 2018), protected areas (Harmáčková \& Vačkář, 2015; Kovács et al., 2015), and natural places such as forests (Wang \& Fu, 2013; Gonzalez-Redin et al., 2016; Pang et al., 2017; Sacchelli, 2018), mountains (Sherrouse et al., 2017), plateaus (Feng et al., 2017), and marine environments (James et al., 2013).

Even though ES trade-off and synergy studies have the potential to become a major tool for policy development and decision-making on global, national, regional, and local scales (Burkhard \& Maes, 2017), practical applications for real-world planning processes (Förster et al., 2015; Bendor et al., 2017; Cord et al., 2017) and land management decisions (Rounsevell et al., 2010; Geneletti, 2013; Deng et al., 2016) using spatial integrated approaches (MEA, 2005; Nelson et al., 2009; Turner et al., 2016; Cord et al., 2017) and scenario building (Deng et al., 2016; Hu et al., 2018) are among research gaps that need to be addressed.

Additionally, the gap between science and practice, or the application of scientific knowledge to face society's challenges (science-policy gaps), is another issue for effective decision-making, because it depends on how knowledge is produced and communicated/integrated. Different levels of policy formulation also influence the process - at the macro-level, the complexity can be greater and the ambiguity brought by science can further complicate the debate, while at the local level of frontline practice and management, there may be fewer factors to be addressed (Bertuol-Garcia et al., 2018).

Another point of translating science into policy is scientific uncertainty. Whereas scientists are familiar with uncertainty and complexity, the public and policy makers often seek certainty and deterministic solutions (Bradshaw \& Borchers, 2000). So fostering joint knowledge-production processes between scientists and decision-makers as well as interdisciplinary research across Ecology, Conservation and Political Science is needed (Bertuol-Garcia et al., 2018).

Pires et al. (2018) mention that Brazil has an unique opportunity to develop research on their links with human well-being due to global relevance the country's stock of biodiversity and ES. Considering that biodiversity research on the links with ES and human well-being in Brazil is in its early phases, they have recommended the promotion of studies that explore multiple relationships between humans and nature.

This paper, therefore, was organized to review: 1) Ecosystem service relationships and scenario approach; and 2) methods to model ecosystem services relationships. Based on publications available on electronic databases, a comprehensive assessment of existing academic research was conducted to explore how the analysis of relationships between ES and spatial modeling improve scenario-building processes, helping to understand different land management effects on ecosystem and human well-being and to identify pathways towards sustainable and balanced land use. 


\section{Methods}

A broad systematic literature review of peer-reviewed articles was conducted using the science direct and google scholar database to capture scientific papers and relevant reports, as those related to Intergovernmental Platform on Biodiversity and Ecosystem Services (IPBES) conceptual framework (Díaz et al., 2015). The search was restricted to the period between 2005 (year of publication of Millennium Ecosystem Assessment) and 2019. An initial screening of articles was done using the following keywords: "ecosystem service*" AND ((synerg*) OR (trade-off* OR trade off* OR tradeoff*)) AND "scenario*" in "Title, abstract or author-specified keywords'.

Then, the following selection criteria was applied to select the papers that were used in this review: (i) relevancy of abstracts and conclusions; (ii) articles that were not written in English were removed; (iii) the relationships identified between services (synergy, trade-off or no relationship) were the main topic; (iv) the method used to evaluate ES relationships was spatial analysis; (v) future scenarios were elaborated comparing the ES.

Accordingly, this paper was structured as follows. Section 3 presents a conceptual framework on the link among scenarios, models and ES relationships in policy and decision-making. Section 4 explores different models and tools for evaluating ES, their relationships, and their association with drivers of changes. Ultimately, at Section 5, we discuss some challenges and opportunities for decision-makers and planners to take appropriate land-management measures considering ES trade-offs and synergies and scenarios modelling.

\section{Ecosystem service relationships and scenario approach}

Scenarios are designed to explore a wide range of circumstances with varied aims, such as testing possible impacts, assisting policy-making and decision-making, promoting raising awareness and stakeholders' engagement, developing innovative research, and understanding the changes in ecosystems and the services they provide (Peterson et al., 2003; Carpenter et al., 2005; Lambin \& Geist, 2006; Hernandez et al., 2010; Kepner et al., 2012).

Scenario-building for ES analysis is an approach applied in the MEA (2005) to clarify key issues that might otherwise be missed or dismissed, as well as suggesting answers and guidance for action. The central idea behind scenario-building is to examine multiple plausible, possible, probable and/ or preferable futures for one or more components of a system, based on a coherent and internally consistent set of assumptions about driving forces, uncertainties and unknowns, key relationships, and certain approaches or decisions (Peterson et al., 2003; Carpenter et al., 2005; Lambin \& Geist, 2006; Hernandez et al., 2010; Kepner et al., 2012; IPBES, 2016; Kröger \& Schäfer, 2016).

Scenario analysis in ecosystem assessments, policy support, and decision-making aims to visualize future impacts on ES and human well-being as a result of global, regional, and local changes such as land use, invasive alien species, over-exploitation, climate change, and pollution. This analysis approach provides support for decisions related to developing adaptive management strategies and exploring the implications of alternative social-ecological development pathways and policy options. At the 
same time, scenario analysis and scenario planning have been successfully applied in national, regional, and global assessments (Burkhard \& Maes, 2017). There has been an increasing number of ES analyses that include demonstrating future changes using different scenarios/policies (Hasegawa et al., 2018). In policy implementation, scenario and model approaches are often used to help identify which landscape activities will be allowed or encouraged in order to achieve landscape-level objectives for a range of criteria such as agricultural productivity, tourism service provision, and biodiversity conservation (IPBES, 2016).

Drivers are the foundation of scenarios because they shape the direction, magnitude, and rate of future landscape and seascape modifications (Mckenzie et al., 2012). Direct/indirect drivers (MEA, 2005) are the factors, both natural and human-induced, which cause ecosystem change (Carpenter et al., 2005; Nelson, 2005; Nelson et al., 2009). Direct drivers (e.g., habitat change, nutrient enrichment, pollution of air, land, and water, overexploitation of terrestrial, marine, and freshwater resources, climate change, invasive alien species) have an explicit effect on ecosystem processes (Nelson, 2005), usually causing physical change that can be identified and monitored (Ash et al., 2010). In contrast, indirect drivers (e.g., demographic changes, economic growth, shifts in socio-political and policy trends, cultural and behavioral changes, and advances in science and technology) operate more diffusely by altering the level or rate of change of one or more direct drivers (Nelson, 2005; Ash et al., 2010). Both types of drivers often operate synergistically, and the combined impacts of various direct and indirect drivers have resulted in significant ES changes (Carpenter et al., 2005).
The assessment of relationships among ES involves identifying what kind of associations occur in time and space as a result of different drivers of changes. When an overall ES relationship is altered, changes in one ES may modify the state of other ES. These changes can be unidirectional, bidirectional, or multidirectional; positive/synergistic, negative/ conflicting, or null. Changes may be a result of shared drivers or ecological processes, or through true interactions among services (Bennett et al., 2009; Mouchet et al., 2014; Spake et al., 2017).

The term trade-off has become very popular in ES literature, analyzing spatial and/or temporal co-occurrences of ES. This concept has predominantly been used to show opposing trends in ES associations and to identify a "win-lose" or "lose-win" situation that involves a decrease in the supply of certain types of ES, either directly or indirectly, because of an increased use of other types of ES (Rodríguez et al., 2006; Bennett et al., 2009; Haase et al,. 2012; Mouchet et al., 2014; Kain et al., 2016; Tomscha \& Gergel, 2016; Cord et al., 2017; Li et al., 2018; Turkelboom et al., 2018).

In turn, a "win-win" situation or positive interaction that involves a mutual improvement of two or more ES is typically called a synergy (Scholes et al., 2010; Haase et al., 2012; Howe et al., 2014; Mouchet et al., 2014; Kain et al., 2016; Lee \& Lautenbach, 2016; Tomscha \& Gergel, 2016; Spake et al., 2017; Li et al., 2018). Some authors use synergies to describe changes made in the same direction, encompassing both win-win and lose-lose situations, situations in which both services either increase or decrease (Bennett et al., 2009).

When two or more types of ES do not appear to increase or decrease, i.e., an improvement in one ES and no obvious changes in the other ("win-no 
change') or a decline in one ES and no obvious changes in the other (lose-no change) (Haase et al., 2012), a 'no relationship/no-effect' relationship (Hamilton, 2008; Lee \& Lautenbach, 2016; Li et al., 2017; Li et al., 2018), or co-existence (Kain et al., 2016), occurs. Individual or bundles of ES can be an object of analysis.

Bundles have been used for investigating interactions among ES, positively or negatively associated, that repeatedly occur together in space or time, across a landscape, and are demanded by different groups of stakeholders (Raudsepp-Hearne et al., 2010; Spake et al., 2017). Wright et al. (2017), for instance, searching the literature to identify and classify formats used to present combinations of ES information for decision making, concluded that bundle maps and diagrammatic representations of bundles as the most likely to support decision-making-based on salience, credibility and legitimacy criteria.

Stakeholders and their differing values, interests, needs, power, and choices are key elements in ES relationship analyses, because they are the prime actors that ultimately cause ES trade-offs and find solutions to alleviate conflict situations. Social, economic, institutional, and ecological factors influence stakeholders' choices in local settings; however, location-based studies focusing on the local specificities of trade-off mechanisms involving local knowledge are limited. The unidirectional knowledge, or one-way flow of knowledge from science to practice, influence democratic decision-making processes and is one of the causes of science-policy gap, as stated by Bertuol-Garcia et al. (2018).
In the context of policy implementation and decision-making ${ }^{1}$, the study of ES relationships can be translated to land-use or management choices that alter one (or more) ES at the expense of the delivery of another (Turkelboom et al., 2018), revealing the effect of an implemented land-use policy (Hu et al., 2018). Thus, this kind of analysis has the potential to provide information to decision makers for better management strategies and policies (Carden et al., 2013), helping to explore optimal land use patterns that can improve ES (Feng et al., 2017; Sun \& Li, 2017). Consequently, ES analysis can help reduce stakeholder conflict, contributing to a more informed and transparent decision-making process (Carden et al., 2013). An assessment based on ES trade-offs is a powerful tool that can be used to design spatial policies and evaluate the effect of land use strategies on the capacity of the landscape to provide goods and services (De Groot et al., 2010). Allowing the integration of ecological-social data in planning (Bendor et al., 2017) helps to prevent negative environmental costs of land use plans or policies (Barral \& Oscar, 2012).

As ES is a global approach, another important aspect is related to differences between worldviews, cultures and languages in achieving fruitful engagement and dialogue in different contexts. The research developed by Intergovernmental Science-Policy Platform on Biodiversity and Ecosystem Services (IPBES), for example, stresses the importance of integrating a range of mixed worldviews and practices regarding multiple values of nature, as highlighted by Coscieme et al. (2020).

Choices or management decisions made between alternatives that cannot be achieved at the sa-

\footnotetext{
${ }^{1}$ We consider decision makers "those people who are aware of the importance of decision made by them or at least reflect on the way these decisions are made", as defined by Wierzbicki \& Wessels. (2000, p. 29).
} 
me time result in changes of the types, magnitudes, and interactions of ES (Cord et al., 2017) and may or may not be reversible (Rodríguez et al., 2006). Such changes may be the result of explicit choices that arise without premeditation or awareness and can take place in the same location or in different areas (e.g., impacts on water-related ES in a watershed) because changes occur spatially (across locations) and temporally (over time) (Rodríguez et al., 2006; Coates et al., 2013; Howe et al., 2014).

Moein et al. (2018) developed a categorization scheme of competitive land-use, outlining the relative effects of a corresponding scenario on the loss of agricultural fields and fertile soils. That study demonstrates the potential that scenario-based urban growth allocation efforts have for evaluating the trade-offs between various policy options and the loss of agricultural productivity, which might help decision makers design urban landscapes with less competition from farmlands. Another study, conducted by Sun \& Li (2017), assessed the spatiotemporal changes and elaborated on alternative scenarios exploring optimal land use strategies that can provide greater ES values and minimize the trade-offs among various ES, providing a reference for sustainable development in urbanized regions of China. Gonzalez-Redin et al. (2016) evaluated implications and trade-offs between forest production and conservation measures to preserve biodiversity in forested habitats; the spatial models produced provided different alternatives for suitable sites that can be used by policy makers to support conservation priorities while addressing management options.

A conceptual framework to illustrate key components of interactions among scenario-building, trade-off analysis, and ES modelling used in decision-making processes is shown in Figure 1. This framework emphasizes a modelling approach in scenario analysis to integrate feedbacks and trade-offs across temporal and spatial scales among dynamic societal economic and natural systems, helping to address particularly complex challenges and guide decision making (IPBES, 2016). We also indicate the importance of considering available data, decision makers' involvement, as well as the complexity of relationships between ES and their drivers. Conceptual frameworks help to organize various ways of thinking about the subject at hand and are useful as a model to guide the assessment process. Although it is not possible to capture the whole reality in conceptual framework, simplification can be a useful and indispensable tool for clarifying and focusing an assessment process (Tomich et al., 2010).

Among the different methods that can be applied to ES relationship analyses under future scenarios, Figure 1 highlights the modelling approach. A model is a simplification of reality that represents qualitative or quantitative descriptions of key system components and relationships between two or more sets of factors (IPBES, 2016; Dunford et al., 2017). When used in ES research, models are generally used to predict ES changes or underlying environmental aspects from which ESs are derived (Dunford et al., 2017). In combination with scenario-building, modelling, and mapping, multiple ESs have been used to clarify the causes of ecosystem change as well as the relationships among ecosystem processes (trade-offs and synergies) to help decision makers make smart and sustainable decisions benefiting human well-being. 


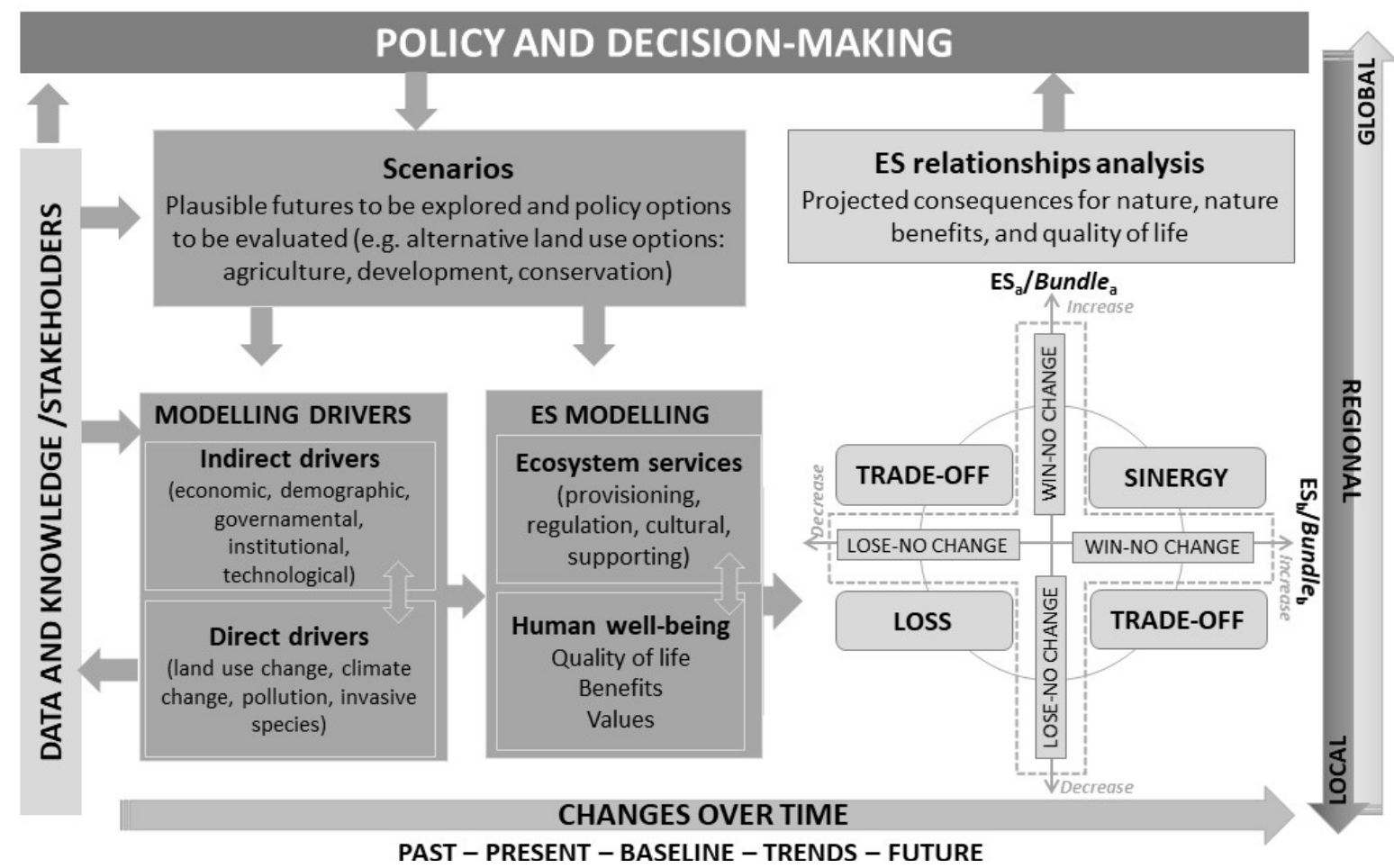

FIGURE 1 - Conceptual framework to illustrate the linkages between scenarios, models, and relationships among ES for informing policy and decision-making. The arrows represent the links between the elements of the framework.

SOURCE: Adapted from Haase et al. (2012); IPBES (2016) and Kain et al. (2016).

\section{Modelling ecosystem services relationships}

Models and scenarios that integrate trade-offs across temporal and spatial scales and among dynamic societal economic and natural systems can address particularly complex challenges and guide decision-making (IPBES, 2016). Moein et al. (2018), for example, studied the potential of scenario-based urban growth allocation efforts to evaluate the trade-offs among various policy options and assess the loss of agricultural productivity using a multi-criteria decision analysis and weighted linear combination map integration procedure. Mukul et al. (2017) conducted a study in Bangladesh identifying the crucial potential for ES framework on sustainable land-use planning and management in the Satchari National Park, concluding that ES assessment, maps, and scenarios were useful for selecting suitable management actions to achieve biodiversity conservation and protected area objectives in the country. 
The use of different methods allows assessment of the current state of ESs (specific or bundle), their relationships, and the influence of drivers of change in scenario analysis. Burkhard et al. (2018); Dunford et al. (2018) and Harrison et al. (2018) mention the following group of methods according to the type of ES values they assessed: biophysical methods for mapping or modelling ecosystems; socio-cultural methods for understanding preferences or social values in ES (using multi-criteria analysis, ranking, and surveys); and monetary techniques for estimating economic values of services.

Based on literature review of peer-reviewed articles, a total of 33 tools that assess, quantify, model, value, and/or map ecosystem services was identified (Appendix $1^{2}$ ), as well as the main characteristic for their use for ES evaluation, including availability to the public (open source or private software), data needed, scale of application, skills required, the operational time necessary to run the model, ES modelled, datasets and examples of applications in research studies.

Integrated Valuation of Ecosystem Services and Trade-offs - InVEST, ARtificial Intelligence for Ecosystem Services - ARIES, Soil and water assessment tool - SWAT, Land Utilisation and Capability Indicator - LUCI and Resource Investment Optimization System model - RIOS are the most common tools supported by published peer-reviewed scientific studies.

Although the other tools presented in Appendix 1 have been recognized as specialized software for spatially modelling ES by different authors (Bagstad et al., 2013; Turner et al., 2016; Grêt-Regamey et al., 2017; Ochoa \& Urbina-Car- dona, 2017; Shoyama et al., 2017), they are only documented in technical project reports, websites and manuals, a situation consistent with the findings of Martínez-Harms \& Balvanera (2012), Olosutean (2015) and Ochoa \& Urbina-Cardona (2017). A better documentation of what is being mapped, how demand is quantified, and from what aim the maps are created are all essential to further operationalize ES assessments (Wolff et al., 2015).

Some tools require affordable and tuition-training programs to ensure the correct use for spatially modelling ES; however, there are many user-friendly and open source modelling tools available as well. Various modelling frameworks and tools have undertaken innovative efforts in addressing the challenges mentioned, for example, combining quantitative indicator systems, spatially explicit mapping features, and qualitative stakeholder perception in a complementary way (Inostroza et al., 2017).

Land use/land cover (LULC) data are key inputs for many ES assessments conducted using these methods. InVEST combines LULC data with supply and demand information for ES to provide a service output value in biophysical or economic terms (Sharps et al., 2017). SWAT applies land use changes to model the effects on watershed yield, sediment, and agricultural pollutants in a river basin (Vigerstol \& Aukema, 2011). The LULC change model outputs serve as inputs for ES models developed using the ARIES platform (Zank et al., 2016). LULC models ES conditions and identifies locations where interventions or improvements might be delivered (Sharps et al., 2017). Using widely available data on land use/management,

\footnotetext{
${ }^{2}$ Tools are organized from the most cited to the least cited in Appendix 1.
} 
climate, soils, topography, and service demands, RIOS is able to provide both an investment portfolio as well as a set of land use scenarios that represent the portfolio implemented in the current landscape (Vogl et al., 2017). In addition to the models for ES assessment, there are also specific models for LULC change such as Conversion Land Use and its Effects (CLUE); Land Transformation Model (Boumans et al., 2015); Land Use Change Analysis System (Martinuzzi et al., 2015); Slope, Land use, Exclusion, Urban extent, Transportation and Hill shade (SLEUTH), GEOMOD; UrbanSim; and Australian continental Land Use Trade-offs (LUTO) models, cited in Agarwal et al. (2002), Verburg et al. (2004), Lambin \& Geist, (2006), Petz (2014) and Connor et al. (2015).

Scientific literature on modelling ES shows that models are used to add quantitative dimensions to scenarios, compare outcomes, evaluate the consistency of scenarios with known conditions and trends, and assess plausibility in relation to generally accepted mechanisms of ecosystem change (Carpenter et al., 2005). Furthermore, because models can explore scenarios, trade-offs that result from different scenarios can subsequently be assessed. Grêt-Regamey et al.(2017) states that some ES modelling tools focus on scenarios, allowing for a better understanding of the impacts of different management practices on ES, such as the localization of ES provision hotspots, the analysis of synergies and trade-offs between ES, or the spatial comparison of supply and demand revealing areas under pressure.

Consistent reviews regarding analytical tools and approaches for quantifying ES synergies and trade-offs on the supply and demand side has recently been published (Howe et al., 2014; Mouchet et al., 2014; Deng et al., 2016; Cord et al., 2017; Spake et al., 2017). These quantitative methods include GIS-based spatial statistical approaches without spatial analysis, integrated modelling framework, and approaches based on the multi-criteria analysis. Assessments that use GIS-based spatial mapping through correlation analysis (for interactions between pairs of ES) or cluster analysis (for ES bundles that are associated in space by delineating spatial units) provide detailed information on ES indicators and assist in understanding and visualizing potential trade-offs via maps and diagrams (Raudsepp-Hearne et al., 2010; Mouchet et al., 2014; Deng et al., 2016; Cord et al., 2017; Spake et al., 2017).

Statistical approaches without the use of spatial analysis (e.g., correlation analysis, regression analysis, cluster analysis, and redundancy analysis) can be used to identify the general direction and strength of trade-offs and synergies (Mouchet et al., 2014; Cord et al., 2017; Li et al., 2018). In integrated modelling framework for systemic assessments, the outputs of one model may be used to provide inputs for another model, creating modelling chains such as InVEST, ARIES, SWAT, LUCI, and RIOS. Multi-criteria analyses are approaches that deal with the implicit trade-offs introducing weights given by both individual decision makers and groups of stakeholders to analyze preferences for different decisional outcomes (Deng et al., 2016; Dunford et al., 2017).

In addition to quantitative methods, qualitative techniques and participatory models may be useful for studying drivers of ES trade-offs, synergies, and bundles. These approaches could include interviews and focus group discussions (Cord et al., 2017). The involvement of scientists, local experts and 
stakeholders in this process enhances the credibility, salience, and legitimacy of ES relationship information, provides inputs for assessment tools, supports interpreting early results, creates a mutual understanding of the problem, and educates how to use outputs to inform decisions (Ruckelshaus et al., 2015). Daw et al. (2015), for example, identified ES trade-offs and their drivers, and evaluated resulting stakeholder perception. Kovács et al. (2013) assessed local stakeholder perception of trade-offs between ESs at three protected sites in the Great Hungarian Plain using qualitative methods. Adams et al. (2016) analyzed land-use scenarios using expected stakeholder satisfaction with changes in the catchment to explore how these scenarios performed against social preferences. Darvill \& Lindo (2016) quantified different use for 15 cultural and provisional ecosystem service indicators across seven stakeholder groups in a watershed environment.

Once ESs have been quantified, spatial and temporal trends in the distribution of two or more ES values can be compared to find significant associations or interactions among them. Assessing current ES relationships provides a baseline for comparing alternative future scenarios and insights into potential outcomes of policy and management decisions (Mouchet et al., 2014).

\section{Challenges and opportunities for ecosystem services in policy development support}

Modelling ecosystem services and its trade-offs and synergies can be useful for predicting changes and effects of land management choices on its fragile ecosystems.
Nevertheless, relations among ES are not stationary in space and time, which makes the complex temporal and spatial ecological dynamics difficult to model. The non-linear dynamics among ES in different trajectories that social-ecological systems can undergo, driven by both biophysical drivers and management decisions, imply that the analyses have to deal with multiple dimensions, interactions, variations, and uncertainties with different physical units across time and space (Cavender-Bares et al., 2015; Deng et al., 2016). Moreover, ES relationships often have ramifications far beyond the decision that has led to the trade-off itself and may affect nearby services, faraway services, future services, or secondary services, and might have serious implications for making trade-off decisions (Rodríguez et al., 2006).

The importance of including society and multiple stakeholders in future scenario analyses to accurately assess ES relationships for policy and decision-making is notable. A more participative approach to define when and what kind of ES relationships information is needed ("value for whom?" and "value as of when?") is critical to inform decision-making, policies, and implementation (Ruckelshaus et al., 2015; Dunford et al., 2017).

Despite this relevance, it is difficult to consider different values in different social contexts in response to changing environmental, socio-economic, or political factors, such as a changing climate, political tensions, trade bans or new supply opportunities given that values are not static and vary depending on which groups place a value on ESs (Dunford et al., 2017).

In this sense, it is pressing to advance in the knowledge and innovation associated to the adoption of flexible measures of adaptive management 
and the implementation of practices of socio-environmental governance in an integrated and interdependent perspective based on ES approach.

Spatial modelling of ESs is an emergent research field (Ochoa \& Urbina-Cardona, 2017) and innovative methods for scenario building, ES analysis, and land management practices have great potential to create customized solutions that address practical user needs and to support full integration of the ES framework into land-use planning and policy-making.

Scenario-building and ES relationship analysis can provide a useful way to evaluate the complex interactions within and between natural and human systems, and to predict the effects of ES management or policy actions. The use of modelling approaches to predict ES changes based on possible future land use scenarios allows decision makers to better understand the corresponding consequences of different choices and achieve a solution for the long-term sustainable development of socio-ecological systems (Deng et al., 2016). Additionally, modelling the current state of ecosystems, their drivers of change, and effects on their function over time can inform decisions, strategies, regulations, and policies at different scales which will shape future management in different scenarios (Atkins et al., 2011; Bastian et al., 2012; Bastian et al., 2013).

Some examples of this approach for the decision-making process have recently been developed. Gong et al. (2019), for instance, conducted a study in a mountain-basin area in western China. They analyzed different tradeoffs/synergies relationships illustrated for different land use scenarios. The win-win scenario was used for guiding strategies for sustainable land use and ecosystem management in this area. Hu et al. (2018) put forward four feasible future land-use scenarios (convert paddy land to dry land) and selected an optimal one based on trade-offs among ecosystem services. The study demonstrated the utility of scenario analysis in providing a scientific basis for land-use decisions that integrated social, cultural and physical concerns.

Brazil is a large and environmentally diversified country, but despite these characteristics, there are still several environmental problems that threat the biodiversity and natural resources in this area. Parron et al. (2019) have summarized current knowledge regarding ES in Brazil in order to provide a basis for future research in the country. They concluded that this topic is in full debate by the scientific community, probably because it is recent, and therefore reviews and analyses of work in this area must be consolidated so that consensus may be reached.

Thus, we recommend future work that should address ES interactions and ES bundle dynamics ranging from pristine to highly modified landscapes in time and space. The integration of spatial ES assessment data into planning and decision-making through innovative methods appear to be an important approach for holistic land-use planning and management in the country.

\section{Acknowledgements}

We thank the Institute for Technological Research (IPT/Brazil) for supporting the PhD research and the Institute for Technological Research Foundation (FIPT/Brazil) for the scholarship to the first author during an exchange program at the University of Newcastle, Australia. We are grateful to the International Centre for Balanced Land Use 
(ICBLU), University of Newcastle, Australia, for providing research facilities during an exchange program and all the colleagues from ICBLU which provided insight and expertise that greatly assisted the research. We also thank grant 2015/03804-9 (Thematic Project MacroAmb "Environmental Governance in São Paulo Macro Metropolis in a climate variability context") of São Paulo Research Foundation (FAPESP). Finally, we would like to thank both reviewers and the editor for their insightful comments on the paper, as these comments led us to an improvement of the work.

\section{References}

Adams, V. M.; Pressey, R. L.; Alvarez-Romero, J. G. Using Optimal Land-Use Scenarios to Assess Trade-Offs between Conservation, Development, and Social Values. PLoS ONE, 11(6), e0158350, 2016. doi: 10.1371/journal.pone.0158350

Agarwal, C.; Green, G. M.; Grove, J. M.; Evans, T. P.; Schweik, C. M. A Review and Assessment of Land-Use Change Models: Dynamics of Space, Time, and Human Choice. General Technical Report (GTR). NE-297. Newton Square, PA: U.S. Department of Agriculture, Forest Service, Northeastern Research Station, 812-855, 2002. doi: 10.2737/NE-GTR-297

Ash, N.; Blanco, H.; Brown, C.; Garcia, K.; Tomich, T.; Vira, B. Ecosystems and human well-being: A manual for assessment practitioners. Island Press, 2010. Retrieved from: http://www.ecosystemassessments.net/resources/ ecosystems-and-human-well-being-a-manual-for-assessment-practitioners.pdf

Atkins, J. P.; Burdon, D.; Elliott, M.; Gregory. A. J. Management of the marine environment: integrating ecosystem services and societal benefits with the DPSIR framework in a systems approach. Marine Pollution Bulletin, 62(2), 215-226, 2011. doi: 10.1016/j.marpolbul.2010.12.012

Bagstad, K. J.; Semmens, D. J.; Winthrop, R. Comparing approaches to spatially explicit ecosystem service modelling: A case study from the San Pedro River, Arizona. Ecosystem Services, 5, 40-50, 2013. doi: 10.1016/j.ecoser.2013.07.007

Barral, M. P.; Oscar, M. N. Land-use planning based on ecosystem service assessment: A case study in the Southeast Pampas of Argentina. Agriculture, Ecosystems and Environment, 154, 34-43, 2012. doi: 10.1016/j.agee.2011.07.010

Bastian, O.; Haase, D.; Grunewald, K. Ecosystem properties, potentials and services - The EPPS conceptual framework and an urban application example. Ecological Indicators, 21, 7-16, 2012. doi: 10.1016/j.ecolind.2011.03.014

Bastian, O.; Syrbe, R.; Rosenberg, M.; Rahe, D.; Grunewald. $\mathrm{K}$. The five pillar EPPS framework for quantifying, mapping and managing ecosystem services. Ecosystem Services, 4, 15-24, 2013. doi: 10.1016/j.ecoser.2013.04.003

BenDor, T. K.; Spurlock, D.; Woodruff, S. C.; Olander, L. A research agenda for ecosystem services in American environmental and land use planning. Cities, 60, 260-271, 2017. doi: 10.1016/j.cities.2016.09.006

Bennett, E. M.; Peterson, G. D.; Gordon, L. J. Understanding relationships among multiple ecosystem services. Ecology Letters, 12(12), 1394-1404, 2009. doi: 10.1111/j. 1461-0248.2009.01387.x

Bertuol-Garcia D.; Morsello C.; N El-Hani C.; Pardini, R. A conceptual framework for understanding the perspectives on the causes of the science-practice gap in ecology and conservation. Biological Reviews of the Cambridge Philosophical Society; 93(2), 1032-1055, 2018. doi: 10.1111/brv.12385

Boumans, R.; Roman, J.; Altman, I.; Kaufman, L. The Multiscale Integrated Model of Ecosystem Services (MIMES): Simulating the interactions of coupled human and natural systems. Ecosystem Services, 12, 30-41, 2015. doi: 10.1016/j.ecoser.2015.01.004

Bradshaw, G. A.; Borchers, J. G. Uncertainty as information: narrowing the science-policy gap. Conservation Ecology. 4(1), 1-7, 2000. doi: 10.1111/brv.12385

Burkhard, B.; Santos-Martín, F. Nedkov, S.; Maes, J. An operational framework for integrated Mapping and Assessment of Ecosystems and their Services (MAES). One 
Ecosystem, 3, 2018. doi: 10.3897/oneeco.3.e22831

Burkhard, B.; Maes, J. Mapping Ecosystem Services. Sofia: Pensoft Publishers, 2017. Retrieved from: https://ab.pensoft. net/article/12837/download/pdf/

Carden, K.; White, C.; Gaines, S. D.; Costello, C. Ecosystem service tradeoff analysis: quantifying the cost of a legal regime. Arizona Journal of Environmental Law \& Policy, 4(39), 40-75, 2013.

Carpenter, S. R.; Pingali, P.L.; Bennett, E.M. Ecosystems and Human Well-Being: Scenarios - Findings of the Scenarios Working Group. Island Press, 2005. Retrieved from: https://www.millenniumassessment.org/documents/ document.356.aspx.pdf

Cavender-Bares, J.; Polasky, S.; King, E.; Balvanera, P. A sustainability framework for assessing trade-offs in ecosystem services. Ecology and Society, 20(1), 1-12, 2015.

Coates, D.; Pert, P. L.; Barron, J.; Muthuri, C.; Nguyen-Khoa, S.; Boelee, E.; Jarvis, D. I. Water-related ecosystem services and food security. In: Boelee, E. (Ed.). Managing water and agroecosystems for food security. Wallingford, UK: CABI, p. 29-41, 2013. (Comprehensive Assessment of Water Management in Agriculture Series 10).

Connor, J. D.; Bryan, B. A.; Nolan, M.; Stock, F.; Gao, L.; Dunstall, S.; Graham, P.; Ernst, A.; Newth, D.; Grundy, M.; Hatfield-Dodds, S. Modelling Australian land use competition and ecosystem services with food price feedbacks at high spatial resolution. Environmental Modelling and Software, 69, 141-154, 2015. doi: 10.1016/j. envsoft.2015.03.015

Cord, A. F.; Bartkowski, B.; Beckmann, M.; Dittrich, A.; Hermans-neumann, K.; Kaim, A.; Lienhoop, N.; Locher-krause, K.; Priess, J.; Schröter-schlaack, C.; Schwarz, N.; Seppelt, R.; Strauch, M.; Václavík, T.; Volk, M. Towards systematic analyses of ecosystem service trade-offs and synergies: Main concepts, methods and the road ahead. Ecosystem Services, 28, 264-272, 2017. doi: 10.1016/j. ecoser.2017.07.012

Coscieme, L.; Hyldmo, H. S.; Fernández-Llamazares, A.; Palomo, I.; Mwampamba, T. H.; Selomane, O.; Sitas, N.; Jaureguiberry, P.; Takahashi, Y.; Lim, M.; Barral, M. P.; Farinaci, J. S.; Diaz-José, J.; Ghosh, S.; Ojino, J.; Alassaf,
A.; Baatuuwie, B. B; Balint, L.; Basher, Z.; Boeraeve, F.; Budiharta, S.; Chen, R.; Desrousseaux, M.; Dowo, G.; Febria, C.; Ghazi, H.; Harmáčková, Z. V.; Jaffe, R.; Kalemba, M. M.; Lambini, C. K.; Lasmana, F. P. S.; Mohamed, A. A. A.; Niamir, A.; Pliscoff, P.; Sabyrbekov, R.; Shrestha, U. B.; Samakov, A.; Sidorovich, A. A.; Thompson, L.; Valle, M. Multiple conceptualizations of nature are key to inclusivity and legitimacy in global environmental governance. Environmental Science \& Policy, 104, 36-42, 2020. doi: 10.1016/j.envsci.2019.10.018

Darvill, R.; Lindo, Z. The inclusion of stakeholders and cultural ecosystem services in land management trade-off decisions using an ecosystem services approach. Landscape Ecology, 31(3), 533-545, 2016. doi: 10.1007/s10980-0150260-y

Daw, T. M.; Coulthard, S.; Cheung, W. W. L.; Brown, K.; Abunge, C.; Galafassi, D.; Peterson, G. D.; McClanahan, T. R.; Omukoto, J. O.; Munyi, L. Evaluating taboo trade-offs in ecosystems services and human well-being. Proceedings of the National Academy of Sciences of the United States of America, 112(22), 6949-6954, 2015. doi: 10.1073/ pnas. 1414900112

De Groot, R.; Fisher, B.; Christie, M. Chapter 1 Integrating the ecological and economic dimensions in biodiversity and ecosystem service valuation. In: Kumar, P. (Ed.). The Economics of Ecosystems and Biodiversity Ecological and Economic Foundations, 1-32, 2010. Retrieved from: http:// hdl.handle.net/2160/37782

Deng, X.; Li, Z.; Gibson, J. A review on trade-off analysis of ecosystem services for sustainable land-use management. Journal of Geographical Sciences, 26(7), 953-968, 2016. doi: 10.1007/s11442-016-1309-9

Díaz, S.; Demissew, S.; Carabias, J.; Joly, C.; Lonsdale, M.; Ash, N; Larigauderie, A.; Adhikari, J. R.; Arico, S.; Báldi, A.; Bartuska, A.; Baste, I. A.; Bilgin, A.; Brondizio, E.; Chan, K. M.; Figueroa, V. E.; Duraiappah, A.; Fischer, M.; Hill, R.; Koetz, T.; Leadley, P.; Lyver, P.; Mace, G. M.; Martin-Lopez, B.; Okumura, M.; Pacheco, P.; Pascual, U.; Pérez, E. S.; Reyers, B.; Roth, E.; Saito, O.; Scholes, R. J.; Sharma, N.; Tallis, H.; Thaman, R.; Watson, R.; Yahara, T.; Hamid, Z. A; Akosim, C.; Al-Hafedh, Y.; Allahverdiyev, R.; Amankwah, E.; Asah, S. T; Asfaw, Z.; Bartus, G.; Brooks, L. 
A.; Caillaux, J.; Dalle, G.; Darnaedi, D.; Driver, A.; Erpul, G.; Escobar-Eyzaguirre, P.; Failler, P.; Fouda, A. M. M; Fu, B.; Gundimeda, H.; Hashimoto, S.; Homer, F.; Lavorel, S.; Lichtenstein, G.; Mala, W. A. Mandivenyi, W.; Matczak, P.; Mbizvo, C.; Mehrdadi, M.; Metzger, J. P.; Mikissa, J. B.; Moller, H.; Mooney, H. A.; Mumby, P.; Nagendra, H.; Nesshover, C.; Oteng-Yeboah, A. A.; Pataki, G.; Roué, M.; Rubis, J.; Schultz, M.; Smith, P.; Sumaila, R.; Takeuchi, K.; Thomas, S.; Verma, M.; Yeo-Chang, Y.; Zlatanova, D. The IPBES Conceptual Framework - connecting nature and people, Current Opinion in Environmental Sustainability, 14, 1-16, 2015. doi: 10.1016/j.cosust.2014.11.002

Dunford, R. W.; Harrison, P. A.; Bagstad, K. J. Computer modelling for ecosystem service assessment. In: Burkhard, B.; Maes, J. Mapping Ecosystem Services. Sófia: Pensoft Publishers, p. 124-135, 2017.

Dunford, R.; Harrison, P.; Smith, A.; Dick, J.; Barton, D. N.; Martin-Lopez, B.; Kelemen, E.; Jacobs, S.; Saarikoski, H.; Turkelboom, F.; Verheyden, W.; Hauck, J.; Antunes, P.; Aszalós, R.; Badea, O.; Baró, F.; Berry, P.; Carvalho, L.; Conte, G.; Czúcz, B.; Blanco, G. G.; Howard, D.; Giuca, R.; Gomez-Baggethun, E; Grizzetti, B.; Izakovicova, Z.; Kopperoinen, L.; Langemeyer, J.; Luque, S.; Lapola, D.M.; Martinez-Pastur, G.; Mukhopadhyay, R.; Roy, S. B.; Niemelä, J.; Norton, L.; Ochieng, J.; Odee, D.; Palomo, I.; Pinho, P.; Priess, J.; Rusch, G.; Saarela, S-R.; Santos, R.; van der Wal, J. T.; Vadineanu, A.; Vári, A.; Woods, H.; Yli-Pelkonen, V. Integrating methods for ecosystem service assessment: Experiences from real world situations. Ecosystem Services, 29, 499-514, 2018. doi: 10.1016/j. ecoser.2017.10.014

Feng, Q.; Zhao, W.; Fu, B.; Ding, J.; Wang, S. Ecosystem service trade-offs and their influencing factors: A case study in the Loess Plateau of China. Science of the Total Environment, 607, 1250-1263, 2017. doi: 10.1016/j.scitotenv.2017.07.079

Förster, J., Barkmann, J.; Fricke, R.; Hotes, S. ; Kleyer, M.; Kobbe, S.; Kübler, D.; Rumbaur, C.; Siegmund-Schultze, M. ; Seppelt, R.; Settele, J.; Spangenberg, J. H.; Tekken, V. ; Václavík, T.; Wittmer, H.. Assessing ecosystem services for informing land-use decisions: A problem-oriented approach. Ecology and Society, 20(3), 31, 2015. doi: 10.5751/ ES-07804-200331
Geneletti, D. Assessing the impact of alternative land-use zoning policies on future ecosystem services. Environmental Impact Assessment Review, 40, 25-35, 2013. doi: 10.1016/j. eiar.2012.12.003

Gonzalez-Redin, J.; Luque, S.; Poggio, L.; Smith, R.; Gimona, A. Spatial Bayesian belief networks as a planning decision tool for mapping ecosystem services trade-offs on forested landscapes. Environmental Research, 144, 15-26, 2016. doi: 10.1016/j.envres.2015.11.009

Grêt-Regamey, A.; Sirén, E.; Brunner, S. H.; Weibel, B. Review of decision support tools to operationalize the ecosystem services concept. Ecosystem Services, 26, 306-315, 2017. doi: 10.1016/j.ecoser.2016.10.012

Grizzetti, B.; Liquetea, C.; Antunes, P.; Carvalho, L.; Geamana, N.; Giuca, R.; Leone, M.; McConnellf, S.; Predad, E.; Santos, R.; Turkelboome, F.; Vadineanud, A.; Woods, H. Ecosystem services for water policy: Insights across Europe. Environmental Science and Policy, 66, 179-190, 2016. doi: 10.1016/j.envsci.2016.09.006

Gong, J.; Liu, D.; Zhang, J.; Xie, Y.; Cao, E.; Li, H.; Tradeoffs/synergies of multiple ecosystem services based on land use simulation in a mountain-basin area, western China. Ecological Indicators, 99, 283-293, 2019. doi: 10.1016/j. ecolind.2018.12.027

Haase, D.; Schwarz, N.; Strohbach, M.; Kroll, F.; Seppelt, R. Synergies, Trade-offs, and Losses of Ecosystem Services in Urban Regions: an Integrated Multiscale Framework Applied to the Leipzig-Halle Region, Germany. Ecology and Society, 17(3), 1-17, 2012. doi: 10.5751/ES-04853-170322

Hamilton, L. S. Forests and water: A thematic study prepared in the framework of the Global Forest Resources Assessment 2005. Rome: FAO, 2008. Retrieved from: http:// www.fao.org/3/i0410e/i0410e00.htm

Harmáčková, Z. V.; Vačkář, D. Modelling regulating ecosystem services trade-offs across landscape scenarios in Třeboňsko Wetlands Biosphere Reserve, Czech Republic. Ecological Modelling, 295, 207-215, 2015. doi: 10.1016/j. ecolmodel.2014.10.003

Harrison, P.A.; Dunford, R.; Barton, D. N.; Kelemen, E.; Martín-López, B.; Norton, L.; Termansen, M.; Saarikoski, H.; Hendriks, K.; Gómez-Baggethun, E.; Czúcz, B.; 
García-Llorente, M.; Howard, D.; Jacobs, S.; Karlsen, M.; Kopperoinen, L.; Madsen, A.; Rusch, G.; van Eupen, M.; Verweij, P.; Smith, R.; Tuomasjukka, D.; Zulian, G. Selecting methods for ecosystem service assessment: A decision tree approach. Ecosystem Services, 29, 481-498, 2018. doi: 10.1016/j.ecoser.2017.09.016

Hasegawa, Y.; Okabe, K.; Taki, H. A scenario approach for ecosystem-service changes. Futures, 96, 23-31, 2018. doi: 10.1016/j.futures.2017.11.003

Hernandez, M. W. G.; Kepner, D. G.; Semmens, D. J. The Use of Scenario Analysis to Assess Water Ecosystem Services in Response to Future Land Use Change in the Willamette River Basin, Oregon - Chapter 5. In: Liotta, P.; Kepner, W.; Lancaster, J.; Mouat, D. (Eds.). Achieving Environmental Security: Ecosystem Services and Human Welfare. Amsterdam, Netherlands: IOS Press, p. 265-268, 2010. Retrieved from: https://cfpub.epa.gov/si/si public_record_report.cfm?Lab $=$ NERL\&dirEntryId $=218684$

Howe, C.; Suich, H.; Vira, B.; Mace, G. M. Creating win-wins from trade-offs? Ecosystem services for human well-being: A meta-analysis of ecosystem service tradeoffs and synergies in the real world. Global Environmental Change, 28, 263-275, 2014. doi: 10.1016/j.gloenvcha.2014.07.005

Hu, Y.; Peng, j.; Liu, Y.; Tian, L. Integrating ecosystem services trade-offs with paddy land-to-dry land decisions: A scenario approach in Erhai Lake Basin, southwest China. Science of the Total Environment, 625, 849-860, 2018. doi: 10.1016/j.scitotenv.2017.12.340

Inostroza, L.; Koenig, H.; Brian, R.; Pickard, L.Z. Putting ecosystem services into practice: Trade-off assessment tools, indicators and decision support systems. Ecosystem Services, 26, 303-305, 2017. doi: 10.1016/j.ecoser.2017.07.004

IPBES - Intergovernmental Science-Policy Platform on Biodiversity and Ecosystem Services. The methodological assessment report on scenarios and models of biodiversity and ecosystem services. IPBES, 2016. Retrieved from: https://ipbes.net/assessment-reports/scenarios

James, R. A.; Butler, G. Y.; Wong, D. J.; Metcalfe, M. H., Petina, L. P.; Rao, N.; van Grieken, M. E.; Lawson, T.; Bruce, C.; Kroon, F. J.; Brodie, J. E. An analysis of trade- offs between multiple ecosystem services and stakeholders linked to land use and water quality management in the Great Barrier Reef, Australia. Agriculture, Ecosystems and Environment, 180, 176-191, 2013. doi: 10.1016/j. agee.2011.08.017

Kain, J. H.; Larondelle, N.; Haase, D.; Kaczorowska. A. Exploring local consequences of two land-use alternatives for the supply of urban ecosystem services in Stockholm year 2050. Ecological Indicators, 70, 615-629, 2016. doi: 10.1016/j.ecolind.2016.02.062

Kepner, W. G.; Ramsey, M. M.; Brown, E. S.; Jarchow, M. E.; Dickinson, K. J. M.; Mark, A. M. Hydrologic futures: using scenario analysis to evaluate impacts of forecasted land use change on hydrologic services. Ecosphere, 3(7), 1-25, 2012. doi: 10.1890/ES11-00367.1

Kosmus, M.; Renner, I.; Ullrich, S. Integrating Ecosystem Services into Development Planning. A stepwise approach for practitioners based on the TEEB approach. Eschborn: GIZ, 2012. Retrieved from: https://www.cbd.int/doc/ case-studies/inc/giz-2012-en-integr-ecosys-serv-in-dev-planning.pdf

Kovács, K.; Polasky, S.; Nelson, E.; Keeler, B. B; Pennington, D.; Plantinga, A. J.; Taff, S. J. Evaluating the Return in Ecosystem Services from Investment in Public Land Acquisitions. Public Library of Science PLoS ONE, 8(6), e62202, 2013. doi: 10.1371/journal.pone.0062202.

Kovács, E.; Kelemen, E.; Kalóczkai, A.; Margóczi, K.; Pataki, G.; Gébert, J.; Málovics, G.; Balázs, B.; Roboz, A.; Kovács, E. K.; Mihók, B. Understanding the links between ecosystem service trade-offs and conflicts in protected areas. Ecosystem Services, 12, 117-127, 2015. doi: 10.1016/j. ecoser.2014.09.012

Kröger, M.; Schäfer, M. Scenario development as a tool for interdisciplinary integration processes in sustainable land use research. Futures, 84, 64-81, 2016. doi: 10.1016/j. futures.2016.07.005

Lambin, E. F.; Geist, H. Land-Use and Land-Cover Change: Local Processes and Global Impacts. [s.l.]: Springer, 2006.

Lauf, S.; Haase, D.; Kleinschmit, B. Linkages between ecosystem services provisioning, urban growth and shrinkage - A modelling approach assessing ecosystem service 
trade-offs. Ecological Indicators, 42, 73-94, 2014. doi: 10.1016/j.ecolind.2014.01.028

Lee, H.; Lautenbach, S. A quantitative review of relationships between ecosystem services. Ecological Indicators, 66, 340-351, 2016. doi: 10.1016/j.ecolind.2016.02.004

Li, B.; Wang, W. Trade-offs and synergies in ecosystem services for the Yinchuan Basin in China. Ecological Indicators, 84, 837-846, 2018. doi: 10.1016/j.ecolind.2017.10.001

Li, B; Qiu, J.; Yan, J.; Wan, L.; Wang, P.; Hu, N.; Cheng, W.; $\mathrm{Fu}, \mathrm{B}$. Spatially explicit quantification of the interactions among ecosystem services. Landscape Ecology, 32(6), 1181-1199, 2017. doi: 10.1007/s10980-017-0527-6

Li, B.; Wang, W.; Wang, Y.-C. Comparative analysis of trade-offs and synergies in ecosystem services between Guanzhong Basin and Hanzhong Basin in China. Biogeosciences Discussions, 1, 1-23, 2018. doi: 10.5194/bg-2018-33

Martínez-Harms, M. J.; Balvanera, P. Methods for mapping ecosystem service supply: a review. International Journal of Biodiversity Science, Ecosystem Services \& Management, 8(1-2), 17-25, 2012. doi: 10.1080/21513732.2012.663792

Martinuzzi, S.; Radeloff, V. C.; Joppa, L. N.; Hamilton, C. M.; Helmers, D. P.; Plantinga, A. J.; Lewis, D. J. Scenarios of future land use change around United States' protected areas. Biological Conservation, 184, 446-455, 2015. doi: 10.1016/j.biocon.2015.02.015

Mckenzie, E.; Rosenthal, A.; Bernhardt, J.; Girvetz, E.; Kovacs, K.; Olwero, N.; Toft, J. Developing Scenarios to Assess Ecosystem Service Tradeoffs: Guidance and Case Studies for InVEST Users. Washington: World Wildlife Fund, 2012. Retrieved from: https://naturalcapitalcoalition. org/developing-scenarios-to-assess-ecosystem-service-tradeoffs-guidance-and-case-studies-for-invest-users/

MEA - Millennium Ecosystem Assessment. Ecosystems and Human Well-being: A Framework for Assessment. Washington, DC: Island Press, 2005. Retrieved from: http:// pdf.wri.org/ecosystems_human_wellbeing.pdf

Moein, M.; Asgarian, A.; Sakieh, Y.; Soffianian, A. Scenario-based analysis of land-use competition in central Iran: Finding the trade-off between urban growth patterns and agricultural productivity. Sustainable Cities and Society,
39, 557-567, 2018. doi: 10.1016/j.scs.2018.03.014

Mouchet, M. A.; Lamarque, P.; Martín-López, B.; Crouzat, E.; Gos, P.; Byczek, C.; Lavorel, S. An interdisciplinary methodological guide for quantifying associations between ecosystem services. Global Environmental Change, 28(1), 298-308, 2014. doi: 10.1016/j.gloenvcha.2014.07.012

Mukul, S. A.; Sohel, M. S. I ; Herbohn, J.; Inostroza, L.; König, H. Integrating ecosystem services supply potential from future land-use scenarios in protected area management: A Bangladesh case study. Ecosystem Services, 26, 355-364, 2017. doi: 10.1016/j.ecoser.2017.04.001

Nelson, G. C. Chapter 7 - Drivers of Change in Ecosystem Condition and Services. In: Carpenter, S. R.; Pingali, P. L.; Bennett, E. M. Ecosystems and Human Well-Being: Scenarios. Island Press, p. 173-222, 2005. Retrieved from: https://www.millenniumassessment.org/documents/document.331.aspx.pdf

Nelson, E.; Mendoza, G.; Regetz, J.; Polasky, S.; Tallis, H.; Cameron, D. R.; Chan, K. M. A.; Daily, G. C.; Goldstein, J.; Kareiva, P. M.; Lonsdorf, E.; Naidoo, R.; Ricketts, T. H.; Shaw, M. R. Modelling multiple ecosystem services, biodiversity conservation, commodity production, and tradeoffs at landscape scales. Frontiers in Ecology and the Environment, 7(1), 4-11, 2009. doi: 10.1890/080023

Ochoa, V.; Urbina-Cardona, N. Tools for spatially modelling ecosystem services: Publication trends, conceptual reflections and future challenges. Ecosystem Services, 26, 155-169, 2017. doi: 10.1016/j.ecoser.2017.06.011

Olosutean, H. Methods for Modelling Ecosystem Services: A Review. Management of Sustainable Development, 7(1), 5-12, 2015. doi: 10.1515/msd-2015-0014

Pang, X.; Nordström, E-M.; Böttcher, H.; Trubins, R.; Mörtberg, U. Trade-offs and synergies among ecosystem services under different forest management scenarios The LEcA tool. Ecosystem Services, 28, 67-79, 2017. doi: 10.1016/j.ecoser.2017.10.006

Parron, L.M.; Fidalgo, E. C. C.; Luz, A. P.; Campanha, M. M.; Turetta, A. P. D.; Pedreira, B. C. C. C.; Prado, R. B. Research on ecosystem services in Brazil: a systematic review. Revista Ambiente \& Água, 4(3), 1-17, 2019. doi: 10.4136/ambi-agua.2263 
Peterson, G. D.; Cumming, G. S.; Carpenter, S. R. Scenario Planning: a Tool for Conservation in an Uncertain World. Conservation Biology, 17(2), 358-366, 2003. doi: 10.1046/j. 1523-1739.2003.01491.x

Petz, K. Mapping and modelling the effects of land use and land management change on ecosystem services: from local ecosystems and landscapes to global biomes. Wageningen, The Netherlands, PhD Thesis (Doctorate in Environmental Systems Analysis) - Wageningen University, 2014. Retrieved from: https://edepot.wur.nl/295633

Pires, A. P. F.; Amaral, A. G.; Padgurschi, M. C. G.; Joly, C. A.; Scarano, F. R. Biodiversity research still falls short of creating links with ecosystem services and human well-being in a global hotspot. Ecosystem Services. 34, 68-73, 2018. doi: 10.1016/j.ecoser.2018.10.001

Raudsepp-Hearne, C.; Peterson, G. D.; Bennett, E. M. Ecosystem service bundles for analyzing tradeoffs in diverse landscapes. Proceedings of the National Academy of Sciences, 107(11), 5242-5247, 2010. doi: 10.1073/ pnas.0907284107

Rodríguez, J. P.; Beard, T. D.; Bennett, E.M.; Cumming, G.S.; Cork, S.; Agard, J.; Dobson, A. P.; Peterson, G. D. Trade-offs across Space, Time, and Ecosystem Services. Ecology and Society, 1(11), 1-14, 2006. Retrieved from: http://www.ecologyandsociety.org/vol11/iss1/art28/

Rounsevell, M. D. A.; Dawson, T. P.; Harrison, P. A. A conceptual framework to assess the effects of environmental change on ecosystem services. Biodiversity and Conservation, 19(10), 2823-2842, 2010. doi: 10.1007/ s10531-010-9838-5

Ruckelshaus, M.; McKenzie, E.; Tallis, H.; Guerry, A.; Daily, G.; Kareiva, P.; Polasky, S.; Ricketts, T.; Bhagabati, N.; Wood, S.A.; Bernhardt, J. Notes from the field: Lessons learned from using ecosystem service approaches to inform real-world decisions. Ecological Economics, 115, 11-21, 2015. doi: 10.1016/j.ecolecon.2013.07.009

Sacchelli, S. A Decision Support System for trade-off analysis and dynamic evaluation of forest ecosystem services. iForest - Biogeosciences and Forestry, 11(1), 171-180, 2018. doi: 10.3832/ifor2416-010

Scholes, R. J.; Biggs, R.; Palm, C.; Duraiappah, A. As- sessing state and trends in ecosystem services and human well-being. Chapter 4. In: Ash, N.; Blanco, H.; Brown, C.; Garcia, K.; Tomich, T.; Vira, B. Ecosystems and human well-being: A manual for assessment practitioners. Island Press, p.115-150, 2010.

Sharps, K.; Masante, D.; Thomas, A.; Jackson, B.; Redhead, J.; May, L.; Prosser, H.; Cosby, B.; Emmett, B.; Jones, L. Comparing strengths and weaknesses of three ecosystem services modelling tools in a diverse UK river catchment. Science of the Total Environment, 584-585, 118-130, 2017. doi: 10.1016/j.scitotenv.2016.12.160

Sherrouse, B. C.; Semmens, D. J.; Ancona, Z. H.; Brunner, N. M. Analyzing land-use change scenarios for trade-offs among cultural ecosystem services in the Southern Rocky Mountains. Ecosystem Services, 26, 431-444, 2017. doi: 10.1016/j.ecoser.2017.02.003

Shoyama, K.; Kamiyama, C.; Morimoto, J.; Ooba, M.; Okuro, T. A review of modelling approaches for ecosystem services assessment in the Asian region. Ecosystem Services, 26, 316-328, 2017. doi: 10.1016/j.ecoser.2017.03.013

Spake, R.; Lasseur, R.; Crouzat, E.; Bullock, J. M.; Lavorel, S.; Parks, K. E.; Marije Schaafsma, M.; Bennett, E. M.; Maes, J.; Mulligan, M.; Mouchet, M.; Peterson, G. D.; Schulp, C. J. E.; Thuiller, W.; Turner, M. G.; Verburg, P. H.; Eigenbrod, F. Unpacking ecosystem service bundles: Towards predictive mapping of synergies and trade-offs between ecosystem services. Global Environmental Change, 47, 37-50, 2017. doi: 10.1016/j.gloenvcha.2017.08.004

Sun, X.; Li, F. Spatiotemporal assessment and trade-offs of multiple ecosystem services based on land use changes in Zengcheng, China. Science of the Total Environment, 609, 1569-1581, 2017. doi: 10.1016/j.scitotenv.2017.07.221

Tian, Y.; Wang, S.; Bai; X.; Luo, G.; Xu, Y. Trade-offs among ecosystem services in a typical Karst watershed, SW China. Science of the Total Environment, 566-567, 1297-1308, 2016. doi: 10.1016/j.scitotenv.2016.05.190

Tomich, T. P.; Argumedo, A.; Baste, I.; Camac, E.; Filer, C.; Garcia, K.; Garbach, K.; Geist, H. J.; Izac, A-M.; Lebel, L.; Lee, M.; Nishi, M.; Olsson, L.; Raudsepp-Hearne, C.; Rawlins, M.; Scholes, R.; Noordwijk, M. Conceptual Frameworks for Ecosystem Assessment: Their Development, 
Ownership, and Use. In: Ash, N.; Blanco, H.; Brown, C.; Garcia, K.; Tomich, T.; Vira, B.; Zurek, M. (Eds.). Ecosystems and human well-being: A manual for assessment practitioners. (World Conservation Monitoring). Washington, DC, USA: Island Press, p. 71-113, 2010. Retrieved from: https://abdn.pure.elsevier.com/en/publications/conceptual-frameworks-for-ecosystem-assessment-their-development-

Tomscha, S. A.; Gergel, S. E. Ecosystem service trade-offs and synergies misunderstood without landscape history. Ecology and Society, 21(1), 2016. doi: 10.5751/ES-08345210143

Turkelboom, F.; Leone, M.; Jacobs, S.; Kelemen, E.; García-Llorente, M.; Baró, F.; Termansen, M.; Barton, D.N.; Berry, P.; Stange, E.; Thoonen, M.; Kalóczkai, A.; Vadineanu, A.; Castro, A.J.; Czúcz, B.; Röckmann, C.; Wurbs, D.; Odee, D.; Preda, E.; E. G-M.; Rusch, G. M.; Pastur, G. M.; Palomo, I.; Dick, J.; Casaer, J.; van Dijk, J.; Priess, J.A.; Langemeyer, J.; Mustajoki, J.; Kopperoinen, L.; Baptist, M. J.; Peri, P. L.; Mukhopadhyay, R.; Aszalós, R.; Roy, S. B.; Luque, S,; Rusch, V.. When we cannot have it all: Ecosystem services trade-offs in the context of spatial planning. Ecosystem Services, 29, 566-578, 2018. doi: 10.1016/j.ecoser.2017.10.011

Turner, K. G.; Anderson, S.; Gonzales-Chang, M.; Costanza, R.; Courville, S.; Dalgaard, T.; Dominati, E.; Kubiszewski, I.; Ogilvy, S.; Porfirio, L. Ratna, N.; Sandhu, H.; Sutton, P.C.; Svenning, J-C.; Turner, G.M,; Varennes, Y-D.; Voinov, A.; Wratten, S. A review of methods, data, and models to assess changes in the value of ecosystem services from land degradation and restoration. Ecological Modelling, 319, 90-207, 2016. doi: 10.1016/j.ecolmodel.2015.07.017

Verburg, P. H.; Schot, P.P.; Dijst, M.J.; Veldkamp, A. Land use change modelling: Current practice and research priorities. GeoJournal, 61(4), 309-324, 2004. doi: 10.1007/ s10708-004-4946-y

Vigerstol, K. L.; Aukema, J. E. A comparison of tools for modelling freshwater ecosystem services. Journal of Environmental Management, 92(10), 2403-2409, 2011. doi: 10.1016/j.jenvman.2011.06.040
Vogl, A. L.; Bryant, B. P.; Hunink, J. E.; Wolny, S.; Apse, C.; Droogers, P. Valuing investments in sustainable land management in the Upper Tana River basin, Kenya. Journal of Environmental Management, 195(1), 78-91, 2017. doi: 10.1016/j.jenvman.2016.10.013

Wang, S.; Fu, B. Trade-offs between forest ecosystem services. Forest Policy and Economics, 26, 145-146, 2013. doi: 10.1016/j.forpol.2012.07.014

Wierzbicki, A.P.; Wessels, J. Chapter 2: The Modern Decision Maker. In: Wierzbicki, A. P.; Makowski, M.; Wessels, J. (Eds.). Model-Based Decision Support Methodology with Environmental Applications. Laxenburg: Springer, p. 29-46, 2000.

Wright, W. C. C.; Eppink, F. V.; Greenhalgh. S. Are ecosystem service studies presenting the right information for decision making? Ecosystem Services, 25, 128-39, 2017. doi:10.1016/j.ecoser.2017.03.002

Wolff, S.; Schulp, C. J. E.; Verburg, P. H. Mapping ecosystem services demand: A review of current research and future perspectives. Ecological Indicators, 55, 159-171, 2015. doi: 10.1016/j.ecolind.2015.03.016

Yang, G.; Ge, Y.; Xue,H.; Yang, W.; Shi, Y.; Peng, C.; Du, Y.; Fan, X.; Ren, Y.; Chang, J. Using ecosystem service bundles to detect trade-offs and synergies across urban-rural complexes. Landscape and Urban Planning, 136, 110-121, 2015. doi: 10.1016/j.landurbplan.2014.12.006

Zank, B.; Bagstad, K. J.; Voigt, B.; Villa, F. Modelling the effects of urban expansion on natural capital stocks and ecosystem service flows: A case study in the Puget Sound, Washington, USA. Landscape and Urban Planning, 149, 31-42, 2016. doi: 10.1016/j.landurbplan.2016.01.004 